\title{
Kupeantha yabassi (Coffeeae-Rubiaceae), a new Critically Endangered shrub species of the Ebo Forest area, Littoral Region, Cameroon
}

\author{
Maria G. Alvarez-Aguirre ${ }^{1}$, Martin Cheek ${ }^{1}$ (D) \& Bonaventure Sonkéé,3,4
}

Summary. A new species to science of evergreen forest shrub, Kupeantha yabassi M.G.Alvarez \& Cheek (Coffeeae Rubiaceae), is described, illustrated and compared morphologically with the closely similar species K. pentamera. Restricted so far to a single site in evergreen lowland forest near the Ebo Forest, Yabassi, Littoral Region, Cameroon, this species is Critically Endangered using the IUCN 2012 standard due to habitat clearance driven mainly by agriculture, adding to the growing list of threatened species resulting from anthropogenic pressure on Cameroon forests. A revised key to the six species of Kupeantha is presented. Two distinct geographical and ecological species groupings within the genus are identified and discussed. Notes are given on other narrowly endemic and threatened species in the Ebo Forest area, a threatened centre of diversity important for conservation in the Littoral Region.

Key Words. Biodiversity, conservation, endemic species, extinction, threatened species.

\section{Introduction}

The new species reported in this paper was discovered as a result of a long-running survey of plants in Cameroon to support improved conservation management. The survey is led by botanists from the Royal Botanic Gardens, Kew and IRAD (Institute of Agricultural Research for Development)-National Herbarium of Cameroon, Yaoundé. This study has focussed on the Cross-Sanaga interval (Cheek et al. 2001, 2006) which contains the area with the highest plant species diversity per degree square in tropical Africa (Barthlott et al. 1996), many of which are narrowly endemic, and also the highest generic diversity per degree square in tropical Africa (Dagallier et al. 2020), including endemic genera such as Medusandra Brenan (Peridiscaceae, Breteler et al. 2015; Soltis et al. 2007). The herbarium specimens collected in these surveys formed the foundations for a series of conservation checklists (see below). So far, over 100 new species and several new genera have been discovered and published because of these surveys, new protected areas have been recognised and the results of analysis are feeding into the Cameroon Important Plant Area programme (Cheek et al. 2020) based on the categories and criteria of Darbyshire et al. (2017).

During completion of a paper erecting the genus Kupeantha Cheek (Cheek et al. 2018a), it was noted that a specimen, Leeuwenberg $6400(\mathrm{~K})$, included in the protologue of $K$. pentamera (Sonké \& Robbr.) Cheek (originally described as Calycosiphonia pentamera Sonké \& Robbr. (Sonké et al. 2007), was geographically disjunct from all the other 38 specimens known of that species. Further investigation of this specimen, in connection with preparation of a Conservation Checklist of the Plants of the Ebo Forest, Littoral Region, has shown that the points of difference between this specimen and the other specimens of Kupeantha pentamera (see Table 1 below), are more than sufficient to warrant to name a new species, the sixth in Kupeantha. We propose in this paper to provide evidence to test this hypothesis and to name this species Kupeantha yabassi.

Kupeantha (Coffeeae, Rubiaceae) is a recently described genus in the Argocoffeopsis clade which also comprises Argocoffeopsis Lebrun and Calycosiphonia Pierre ex Robbr., the latter being sister to the first two genera. There are no known morphological synapomorphies that unite the three genera (Cheek et al. 2018a). In that paper two new species were published (Kupeantha ebo M.G.Alvarez \& Cheek and K. kupensis Cheek \& Sonké, while the other three species had previously been described in either Argocoffeopsis or Calycosiphonia: ( $K$. fosimondi (Tchiengué \& Cheek) Cheek (Cheek \& Tchiengué

Accepted for publication 10 August 2021. Published online 5 November 2021

1 Herbarium, Royal Botanic Gardens, Kew, Richmond, Surrey, TW9 3AE, UK. e-mail: m.cheek@kew.org

2 Plant Systematics and Ecology Laboratory, Higher Teacher's Training College, University of Yaoundé I, P.O. Box 047, Yaoundé, Cameroon.

3 Herbarium et Bibliothèque de Botanique Africaine, CP 169, Université Libre de Bruxelles, Av. F. Roosevelt 50, B-1050, Brussels, Belgium.

4 Missouri Botanical Garden, Africa \& Madagascar Department, P.O. Box 299, 63166-0299, St. Louis, Missouri, USA. 
Table 1. Main distinctions between Kupeantha yabassi and K. pentamera

\begin{tabular}{lll}
\hline \hline Character & \multicolumn{1}{c}{ Kupeantha yabassi } & Kupeantha pentamera \\
\hline Leaf blade colour & drying dark green & drying black \\
Secondary nerves & appearance to the leaf surface & flush with surface, \\
& the leaf completely flat \\
Petiole length $(\mathrm{mm})$ & $6-12$ & $(7-) 9-13$ \\
Number of flowers per axil & $(2-) 3(-5)$ & $1(-2)$ \\
Lower calyculus dimensions $(\mathrm{mm})$ & $1.2-1.5 \times 1.2-1.5$ & $0.5-1 \times 0.5-1$ \\
Upper calyculus dimensions $(\mathrm{mm})$ & $2.2-3.5 \times 1-1.5$ & $1-1.5 \times 1-2$ \\
Fruit size (dried) $(\mathrm{mm})$ & $10-13 \times 11-14$ & $17-25 \times 13-16.5$ \\
\hline
\end{tabular}

in Harvey et al. 2010), K. pentamera (Sonké et al. 2008), and K. spathulata (A.P.Davis \& Sonké) Cheek (Davis \& Sonké 2008)). Kupeantha is characterised by having supra-axillary buds, distal stem internodes drying dull black, proximal internodes with smooth, white spongy epidermis. The species all occur in Cameroon, with one of the species extending into Rio Muni of Equatorial Guinea. Kupeantha are found mainly in primary tropical forest from $100-2000 \mathrm{~m}$ altitude (Cheek et al. 2018a). It is possible that in future the range of the genus might be extended to adjacent Gabon, since over 1000 specimens of Rubiaceae were reported unidentified from that country by Sosef $e t a l$. (2006).

\section{Kupeantha yabassi: its range and other endemic species in the Ebo Forest area}

Abwe \& Morgan (2008) and Cheek et al. (2018b) characterise the Ebo forest, which is adjacent to the location of Kupeantha yabassi, and give overviews of habitats, species and importance for conservation. Sixty-nine globally threatened plant species are currently listed from Ebo on the IUCN Red List website and the number is set to rise rapidly as more of Cameroon's rare species are assessed for their conservation status as part of the Cameroon TIPAs programme. The discovery of a new species to science near the Ebo forest is not unusual. Numerous new species have been published from Ebo in recent years. Examples of other species that, like Kupeantha yabassi, appear to be strictly endemic to the Ebo area on current evidence are: Ardisia ebo Cheek (Cheek \& Xanthos 2012), Crateranthus cameroonensis Cheek \& Prance (Prance \& Jongkind 2015), Gilbertiodendron ebo Burgt \& Mackinder (van der Burgt et al. 2015), Inversodicraea ebo Cheek (Cheek et al. 2017), Kupeantha ebo M.G.Alvarez \& Cheek (Cheek et al. 2018a), Palisota ebo Cheek (Cheek et al. 2018b) and Pseudohydrosme ebo Cheek (Cheek et al. 2021).

Further species described from Ebo have also been found further west, in the Cameroon Highlands, particularly at Mt Kupe and the Bakossi Mts (Cheek et al. 2004). Examples are Myrianthus fosi Cheek (Cheek \& Osborne, in Harvey et al. 2010), Salacia nigra Cheek (Gosline \& Cheek 2014), Talbotiella ebo Mackinder \& Wieringa (Mackinder et al. 2010).

Additionally, several species formerly thought endemic to Mt Kupe and the Bakossi Mts have subsequently been found at Ebo, e.g., Coffea montekupensis Stoff. (Stoffelen et al. 1997), Costus kupensis Maas \& H.Maas (Maas-van der Kamer et al. 2016), Microcos magnifica Cheek (Cheek 2017), and Uvariopsis submontana Kenfack, Gosline \& Gereau (Kenfack et al. 2003). It is considered likely that additional Kupe species may yet be found at Ebo such as Brachystephanus kupeensis I.Darbysh. (Champluvier \& Darbyshire 2009), Impatiens frithii Cheek (Cheek \& Csiba 2002) since new discoveries are still frequently being made in the Ebo Forest area. Therefore, it is possible that Kupeantha yabassi might yet also be found in the Cameroon highlands, e.g., at Mt Kupe. However, this is thought to be only a relatively small possibility given the high level of survey effort at Mt Kupe: if it occurred there, it is highly likely that it would have been recorded already.

\section{Materials and Methods}

Herbarium citations follow Index Herbariorum (Thiers, continuously updated). Specimens were studied online, on loan from, or at BR, K, WAG and YA. All specimens cited have been seen. We also searched JSTOR Global Plants (continuously updated) for additional material, and finally the Global Biodiversity Facility (GBIF, (continuously updated). Binomial authorities follow the International Plant Names Index (IPNI continuously updated). The conservation assessment was made using the categories and criteria of IUCN (2012). Herbarium material was examined with a Leica Wild M8 dissecting binocular microscope fitted with an eyepiece graticule measuring in units of $0.025 \mathrm{~mm}$ at maximum magnification. The drawing was made with the same equipment using Leica 308700 camera lucida attachment. The terms and format of the description follow the conventions of Cheek et al. (2018a). The georeference for Leeuwenberg 6400 was obtained from the locality description on the specimen using Google Earth. (https:// www.google.com/intl/en_uk/earth/versions/). 


\section{Taxonomic Treatment}

Kupeantha yabassi can be distinguished from $K$. pentamera to which it is most closely similar, and most easily confused with, using the diagnostic characters presented in Table 1 . It can be distinguished from all other species of the genus using the key. The key is based mainly on vegetative features and fruit, since these are present for all or most (respectively) of the year, and because flowers are unknown in two of the species.

Key to the species of Kupeantha (updated from Cheek et al. 2018a)

1. Fruit obovoid; acumen spathulate $\ldots \ldots \ldots \ldots \ldots \ldots \ldots \ldots \ldots \ldots \ldots \ldots \ldots$ spathulata

1. Fruit globose or ellipsoid; acumen with apex acute $\ldots \ldots \ldots \ldots \ldots$

2. $\quad 0.5$ - $1.5 \mathrm{~m}$ tall; tertiary nerves conspicuous, scalariform or forming fine reticulation on lower surface of leaf-

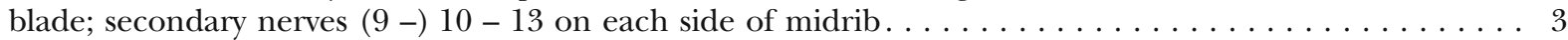

2. $2-5 \mathrm{~m}$ tall; quaternary nerves absent or inconspicuous, scalariform or fine reticulation absent; secondary

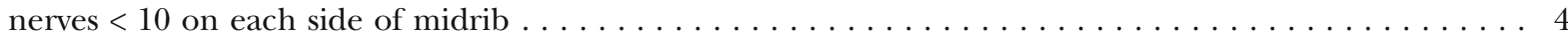

3. Leaves drying black, secondary nerves flush with adaxial surface; inflorescences 1 ( -2$)$ per axil; fruit 17 -

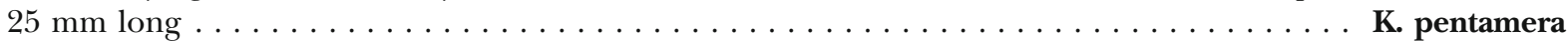

3. Leaves drying green, secondary nerves deeply impressed on adaxial surface; inflorescences (2 -) $3(-5)$ per

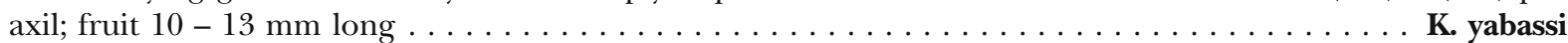

4. Fruits ellipsoid, ripening black, with a short stipe \& rostrum. SW Region, Mt Kupe. . . . . . . .K. kupensis

4. Fruit globose, ripening orange-red, stipe \& rostrum absent or inconspicuous. SW Region, Lebialem or Littoral

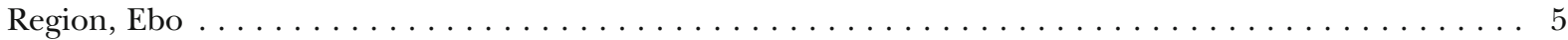

5. Fruit 25 - $30 \mathrm{~mm}$ diam. Lebialem Highlands of SW Region; $1300-1400 \mathrm{~m}$ alt. . . . . . . . . K. fosimondi

5. Fruit $10-15 \mathrm{~mm}$ diam. Ebo Highlands of Littoral Region; $770-830 \mathrm{~m}$ alt . . . . . . . . . . . K. ebo

Kupeantha yabassi M.G.Alvarez $\mathcal{E}$ Cheek sp. nov. Type: Cameroon, Littoral Region, $3 \mathrm{~km}$ east of $\mathrm{km} 21$ of road Yabassi - Douala, $4^{\circ} 19^{\prime} 12^{\prime \prime} \mathrm{N}, 10^{\circ} 04^{\prime} 09^{\prime \prime} \mathrm{E}$, fr, 17 Aug. 1965, A. J. M. Leeuwenberg 6400 (holotype K00609212; isotypes BR0000015677594, WAG0114722 (3 sheets), YA).

http://www.ipni.org/urn:lsid:ipni.org:names:77220450-1

Evergreen shrub $1.50 \mathrm{~m}$ tall, erect. Leafy branchlets with distal internodes drying black, black, terete, $2-3 \mathrm{~mm}$ in diam., internodes $3.8-5.5 \mathrm{~cm}$ long, glabrous, smooth; epidermis of older branches becoming white, flaking and peeling. Stipules shortly sheathing, subcoriaceous, $2-3 \times 1.7-4(-5) \mathrm{mm}$, broadening with distance from the stem apex, keeled along midline, generally from the base, limb triangular, apex subulate, variable in length, $0.5-2 \mathrm{~mm}$ long, detaching and falling with age, outer surface glabrous, inner surface with standard colleters (Fig. 1B - D).

Leaves opposite, equal; leaf-blades slightly bicoloured, drying dark green-brown above and greygreen below, papery, narrowly elliptic to oblong, 8 $17 \times 3-7 \mathrm{~cm}$; apex acuminate, $8-12 \mathrm{~mm}$ long; base attenuate to cuneate; midrib slightly raised above and prominent below; secondary nerves deeply impressed above (leaf surface approaching bullate), prominent below, $9-12$ on each side of the midrib, ascending and uniting to make a looped intramarginal nerve (brochidodromous) $2-2.3 \mathrm{~mm}$ from the margin; midrib and secondary nerves drying black on abaxial surface; tertiary nerves scalariform to broadly reticulate on both sides of the leaf (Fig. 1A), glabrous above and below, domatia absent. Petioles drying black to dark brown, plano-convex, $0.6-1.1 \mathrm{~cm}$ long, $1 \mathrm{~mm}$ wide, the adaxial surface flat, glabrous. Inflorescences supra-axillary, inserted $2-4 \mathrm{~mm}$ above the axil, in consecutive nodes (Fig. 1A), (2 - ) $3(-5)$ per axil, in opposite axils, 1-flowered, subsessile, peduncle 0.8 $1.5 \mathrm{~mm}$ long. Calyculi 2, subsessile, cupuliform, glabrous; the first, proximal, calyculus, closer to the stem, often 4-lobed, $1.2-1.5 \times 1.2-1.5 \mathrm{~mm}$; the second, distal, calyculus, $2.2-3.5 \times 1-1.5 \mathrm{~mm}$, lobes 2, subulate, each $1 \mathrm{~mm}$ long (Fig. 1G). Fruits berry-like, orange at maturity, shortly ellipsoid to globose, $2 \times$ $1.5 \mathrm{~cm}$ when fresh (field notes); $1.1-1.4 \times 1.0-1.3 \mathrm{~cm}$ when dried (Fig. 1E); subsessile, glabrous, exocarp drying hard, leathery, dark brown; disc \pm circular, flat, $2 \mathrm{~mm}$ diam, sunk below calyx rim (Fig. 1F); calyx limbs absent. Seeds 2, apparently without seed coat (Fig. 1J), plano-convex, oblate in outline $9-12 \times 6-10 \times 2-$ $6 \mathrm{~mm}$ surface smooth with hilum elliptic, c. $1 \mathrm{~mm}$ long on ventral face (Fig. 1L), endosperm entirely cream, striated in longitudinal section, embryo about $0.5 \mathrm{~mm}$ long (Fig. 1M). Micropyle not detected.

RECOGNITION. Kupeantha yabassi is an evergreen shrub, similar to $K$. pentamera, but differing in the fruits being smaller, 10 - $13 \mathrm{~mm}$ long (vs 17 - $25 \mathrm{~mm}$ ), inflorescences more numerous, $(2-) 3(-5)$ per axil 

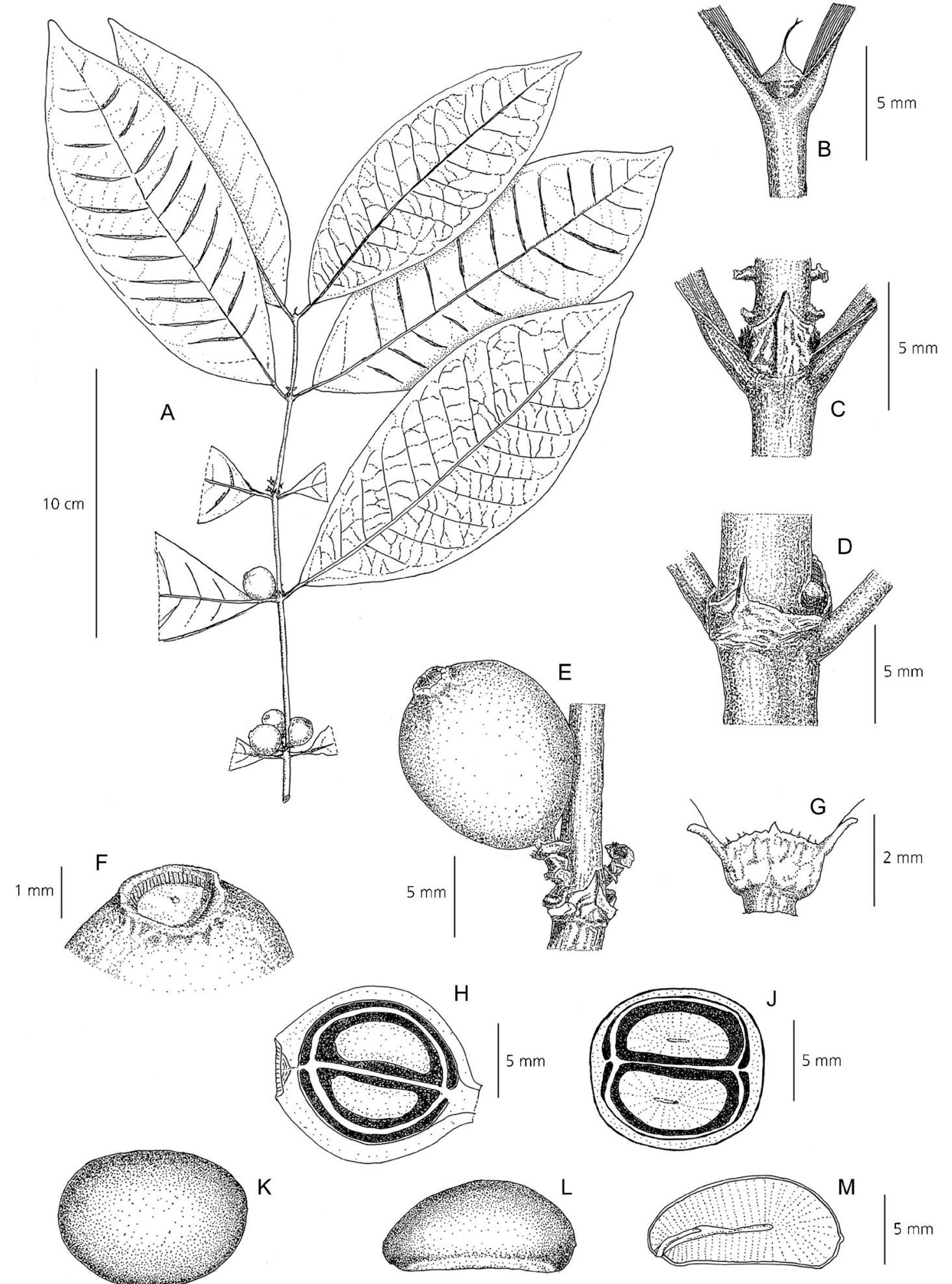

\section{Alvarez @2017}

Fig. 1. Kupeantha yabassi A habit, fruiting branch; B detail of stipules at stem apex; C \& D sheathing stipules and supra-axillary buds at subapical nodes; E fruit, showing calyculi; $\mathrm{F}$ fruit apex showing disc; $\mathrm{G}$ distal (upper) calyculus in young fruit; $\mathrm{H}$ fruit, longitudinal section showing the exocarp (dotted), mesocarp (white areas), cavities (dark areas) and at the centre, the seeds; J transverse section of a fruit, showing the exocarp (dotted), mesocarp (white areas), cavities (dark areas) and at the centre, endosperm with embedded embryo; $\mathrm{K}$ adaxial view of seed; $\mathrm{L}$ lateral view of seed; $\mathrm{M}$ longitudinal section of seed showing the endosperm (hatched) and part of embryo. A - M from A. J. M. Leeuwenberg 6400. DRAWN BY MARIA ALVAREZ. 
(vs 1 ( - 2)), upper calyculus $2.2-3.5 \mathrm{~mm}$ long (vs 1 $1.5 \mathrm{~mm}$ long), leaf-blade drying green, sub-bullate due to the impressed secondary nerves (not black, surface flat). Additional characters distinguishing Kupeantha yabassi from $K$. pentamera are given in Table 1 .

DISTRIBUTION. Endemic to Cameroon. Only known from a single collection made in forest near the Ebo Forest in the Littoral Region.

HABITAT. Secondary forest, along the Yabassi-Douala road, with Lophira alata Banks ex C.F.Gaertn. (Ochnaceae), Coula edulis Baill. (Olacaceae) and Sacoglottis gabonensis (Baill.) Urb. (Humiriaceae), 50 $100 \mathrm{~m}$ altitude. The presence of Lophira alata and Sacoglottis gabonensis in rainforest within c. $50-100 \mathrm{~km}$ from the coast in Cameroon, indicates that the forest has been cultivated in the past (Letouzey 1957, 1960, 1968, 1985). At Ebo the geology is ancient, highly weathered basement complex, with some ferralitic areas in foothill areas which are inland, c. $100 \mathrm{~km}$ from the coast. The wet season (successive months with cumulative rainfall $>100 \mathrm{~mm}$ ) falls between March and November and is colder than the dry season (Abwe \& Morgan 2008).

CONSERVATION STATUS. Kupeantha yabassi is known from only a single site along the road parallel to the western boundary of the Ebo Forest. Since 2006, botanical surveys have been mounted almost annually, at different seasons, over many parts of the proposed National Park of Ebo. About 2500 botanical herbarium specimens have been collected, but this species has not yet been seen in the Ebo Forest. However, the area outside the surroundings of the two research camps in the Ebo Forest has not yet been surveyed for plants. While it is likely that the species will be found at additional sites, likely including the Ebo Forest, there is no doubt that it is genuinely range-restricted. Botanical surveys and other plant studies for conservation management in forest areas north, west and east of Ebo resulting in thousands of specimens being collected and identified have failed to find any additional specimens of this species (Cheek et al. 1996; Cable \& Cheek 1998; Cheek et al. 2000; Maisels et al. 2000; Harvey et al. 2004; Cheek et al. 2004; Cheek et al. 2010; Harvey et al. 2010; Cheek et al. 2011). It is possible that the species is truly localised as are all other species of the genus west of the Sanaga (see discussion below). Kupeantha yabassi may well be unique to the Ebo Forest area, as are also, on current evidence, at least five other species (see discussion, below). The area of occupation of Kupeantha yabassi is estimated as $4 \mathrm{~km}^{2}$ using the IUCN preferred cell-size. The extent of occurrence is the same. In February 2020 it was discovered that moves were in place to convert the forest into two logging concessions (e.g. https://www.globalwildlife.org/blog/ebo-forest-astronghold-for-cameroons-wildlife/ and https:// blog.resourceshark.com/cameroon-approves-logging- concession-that-will-destroy-ebo-forest-gorilla-habitat/ both accessed 19 Sept. 2020). Such logging would result in timber extraction that would open up the canopy and remove the intact habitat in which Kupeantha yabassi is thought to grow. Additionally, slash and burn agriculture often follows logging trails and would negatively impact the population of this species. Fortunately the logging concession was suspended in August 2020 due to representations to the President of Cameroon on the global importance of the biodiversity of Ebo (https://www.business wire.com/news/home/20200817005135/en/Relief-inthe-Forest-Cameroonian-Government-Backtracks-onthe-Ebo-Forest accessed 19 Sept. 2020). However, the forest habitat of this species remains unprotected and threats of logging and conversion of the habitat to plantations remain. Kupeantha yabassi is therefore here assessed, on the basis of the range size given and threats stated as Critically Endangered, CR B1+2ab(iii).

PHENOLOGY. Flowering unknown; fruiting in August. ETYMOLOGY. Kupeantha yabassi is named for the administrative centre nearest to the point where the specimen was collected.

VERNACULAR NAMES. No vernacular names or uses are recorded.

NOTES. Only known from the single collection cited. At Kew the specimen was annotated "indet. not matched in Tricalysia etc.", subsequently loaned to BR in 1983, it was annotated by Robbrecht in 1986 as "unknown to me, I don't believe it belongs to Tricalysia”.

\section{Discussion \\ Groupings within Kupeantha}

The former placement of the only known specimen of Kupeantha yabassi in $K$. pentamera was understandable due to their morphological similarity. Both species have leaves of similar shape and size, and uniquely in the genus have tertiary nerves which are visible (they are inconspicuous in other species of the genus). They also share fruits of similar shape. The six species of Kupeantha can be divided into two groups based on ecology and geography. The groups differ from each other also in sympatry and extent of occurrence. 1) East of the Sanaga river, the only two species present are Kupeantha spathulata and $K$. pentamera. Both species are low altitude, predominantly occurring below $800 \mathrm{~m}$ (although the last has been recorded as high as $900 \mathrm{~m}$ ). Both are known from numerous specimens, 21 and 37 respectively, with numerous locations and large extents of occurrence $\left(8100 \mathrm{~km}^{2}\right.$, and $52 \mathrm{~km}^{2}$ respectively). The two species are often sympatric, indeed have been collected in sequential number series at several of their common locations, in South Region, Cameroon: e.g., Bibondi, 24 Jan. 2005, Sonké Ẽ Nguembou 3783 (K. pentamera) and 3784 
(K. spathulata). Again, at $3 \mathrm{~km}$ NNW Ngoyang, 20 Sept. 2005, Sonké Ẽ Djuikouo 4060 (K. spathulata), and 4059 (K. pentamera). Similarly, at $2 \mathrm{~km}$ NW Mbikililiki, 19 Jan. 2006, Sonké Ẽ Djuikouo 4286 (K. pentamera) and 4285 ( $K$. spathulata). These specimens are cited in the protologues of the two species (Sonké et al. 2008 and Davis \& Sonké 2008), they derive from a series of Rubiaceae-focussed surveys that resulted in numerous other discoveries of new Rubiaceae species to science, e.g., Sonké et al. 2005, 2006 \& 2008). 2) West of the Sanaga River, the four species known, Kupeantha kupensis, K. fosimondi, K. ebo and K. yabassii are all upland species, occurring in the $800-2000 \mathrm{~m}$ altitudinal range (However, Kupeantha ebo occurs in the range $770-830 \mathrm{~m}$ ). None are sympatric but allopatric, all are separated from each other by tens of kilometres. Even in the Ebo forest area, Kupeantha ebo and $K$. yabassi are physically separated by $20 \mathrm{~km}$. These four species all have much smaller extents of occurrence (c. $8 \mathrm{~km}^{2}$ in $K$. kupensis) and are much rarer and more localised (and so more threatened) than those species east of the Sanaga. Despite the separation of these two groups, there is no evidence that they are separated phylogenetically. The two species East of the Sanaga are in fact so dissimilar that they were formerly placed apart from each other in separate genera (Calycosiphonia and Argocoffeopsis, Sonké et al. 2008 and Davis \& Sonké 2008).

Cameroon has been highlighted as the top country in tropical Africa for plant species diversity per degree square and has high levels of endemism (Lachenaud et al. 2013; Onana 2011; Onana \& Cheek 2011). The inventory of its flora is far from completed, and the few remaining sizable areas of intact forest such as Ebo Forest, in the Littoral Region, are seriously threatened by clearance. Unfortunately, there is an increasing pressure to convert critical areas for biodiversity into oil palm plantations, and logging concessions (Mahmoud et al. 2019). The pressure for forest and wildlife resources is a strong driver in the rapid decrease of primary forests and biodiversity. This paper contributes to documenting the rich flora of Cameroon and helps to highlight areas for conservation.

Such discoveries as this new species also underline the urgency for making such further discoveries while it is still possible since in all but one of the cases given, the range extension resulted from discovery of a new species for science with a narrow geographic range and/or very few individuals, and which face threats to their natural habitat, putting these species at high risk of extinction.

About 2000 new species of vascular plant have been discovered each year for the last decade or more. Until species are known to science, they cannot be assessed for their conservation status and the possibility of protecting them is reduced (Cheek et al. 2020). Documented extinctions of plant species are increasing, e.g., Oxygyne triandra Schltr. and Afrothismia pachyantha Schltr. of South West Region, Cameroon are now known to be globally extinct (Cheek \& Williams 1999; Cheek et al. 2018c; Cheek et al. 2019). In some cases, species appear to be extinct even before they are known to science, such as Vepris bali Cheek, also from the Cross-Sanaga interval in Cameroon (Cheek et al. 2018d) and elsewhere, Nepenthes maximoides Cheek (King \& Cheek 2020). Most of the $>800$ Cameroonian species in the Red Data Book for the plants of Cameroon are threatened with extinction due to habitat clearance or degradation, especially of forest for small-holder and plantation agriculture following logging (Onana \& Cheek 2011). Efforts are now being made to delimit the highest priority areas in Cameroon for plant conservation as Tropical Important Plant Areas (TIPAs) using the revised IPA criteria set out in Darbyshire et al. (2017). This is intended to help avoid the global extinction of additional endemic species such as Kupeantha yabassi which we hope will be included in the proposed Ebo Forest IPA.

With only one locality known, Kupeantha yabassi represents another narrowly endemic Cameroonian species threatened with extinction due to deforestation for oil palm plantations, small-scale agriculture, mining and logging (Onana \& Cheek 2011; Cheek et al. 2018a).

\section{Acknowledgements}

This paper was completed as part of the Cameroon TIPAs (Tropical Important Plant Areas) project at RBG, Kew, which is supported by Players of People's Postcode Lottery. Ekwoge Abwe and Bethan Morgan and their team at the Ebo Forest programme are thanked hugely for expediting our botanical surveys in the Ebo Forest of Cameroon over several years which allowed us to give context about the Ebo Forest in this paper.

The heads of IRAD (Institute of Agricultural Research for Development)-National Herbarium of Cameroon, Yaoundé, successively Jean-Michel Onana, Florence Ngo Ngwe, Eric Nana and Jean Betti Lagarde, are thanked for co-ordinating the cooperation with the Royal Botanic Gardens, Kew.

The authors would like to thank two anonymous reviewers for comments on an earlier version of this manuscript.

Open Access This article is licensed under a Creative Commons Attribution 4.0 International License, which permits use, sharing, adaptation, distribution and reproduction in any medium or format, as long as you give appropriate credit to the original author(s) and the source, provide a link to the Creative Commons licence, and indicate if changes were made. 
The images or other third party material in this article are included in the article's Creative Commons licence, unless indicated otherwise in a credit line to the material. If material is not included in the article's Creative Commons licence and your intended use is not permitted by statutory regulation or exceeds the permitted use, you will need to obtain permission directly from the copyright holder. To view a copy of this licence, visit http://creativecommons.org/ licenses/by/4.0/.

\section{References}

Abwe, E. E. \& Morgan, B. J. (2008). The Ebo Forest: four years of preliminary research and conservation of the Nigeria-Cameroon chimpanzee (Pan troglodytes vellerosus). Pan Africa News 15: 26 - 29. https:// doi.org/10.5134/143494

Barthlott, W., Lauer, W. \& Placke, A. (1996). Global distribution of species diversity in vascular plants: towards a world map of phytodiversity. Erkunde 50: 317 - 328 (with supplement and figure).

Breteler, F. J., Bakker, F. T. \& Jongkind, C. C. (2015). A synopsis of Soyauxia (Peridiscaceae, formerly Medusandraceae) with a new species from Liberia. Pl. Ecol. Evol. 148 (3): 409 - 419. https://doi.org/ 10.5091/plecevo.2015.1040

Cable, S. \& Cheek, M. (1998). The plants of Mt Cameroon, a conservation checklist. Royal Botanic Gardens, Kew.

Champluvier, D. \& Darbyshire, I. (2009). A revision of the genera Brachystephanus and Oreacanthus (Acanthaceae) in tropical Africa. Syst. Geogr. Pl. 79: 115 - 192.

Cheek, M. (2017). Microcos magnifica (Sparmanniaceae) a new species of cloudforest tree from Cameroon. PeerJ 5:e4137. https://doi.org/ $10.7717 /$ peerj. 4137

\& Csiba, L. (2002). A new epiphytic species of Impatiens (Balsaminaceae) from western Cameroon. Kew Bull. 57 (3): 669 - 674. https://doi.org/ $10.2307 / 4110997$

\& Williams, S. (1999). A Review of African Saprophytic Flowering Plants. In: J. R. Timberlake \& S. Kativu (eds), African Plants. Biodiversity, Taxonomy $\mathcal{E}$ Uses. Proceedings of the 15th AETFAT Congress at Harare, Zimbabwe, pp. 39 - 49. Royal Botanic Gardens, Kew.

\& Xanthos, M. (2012). Ardisia ebo sp. nov. (Myrsinaceae), a creeping forest subshrub of Cameroon and Gabon. Kew Bull. 67: 281 - 284. https:/ / doi.org/10.1007/s12225-012-9362-8

Achoundong, G., Onana, J-M., Pollard, B., Gosline, G., Moat, J. \& Harvey, Y. B. (2006). Conservation of the Plant Diversity of Western Cameroon. In: S. A. Ghazanfar \& H. J. Beentje (eds), Taxonomy and ecology of African plants, their conservation and sustainable use. Proceedings of the 17th AETFAT Congress, Addis Ababa, Ethiopia: pp. 779 - 791. Royal Botanic Gardens, Kew.

Alvarez-Aguirre, M. G., Grall, A., Sonké, B., Howes, M. J. R. \& Larridon, I. (2018a). Kupeantha (Coffeeae, Rubiaceae), a new genus from Cameroon and Equatorial Guinea. PLoS ONE 13 (6): e 0199324 . https://doi.org/10.1371/ journal.pone.0199324

Cable, S., Hepper, F. N., Ndam, N. \& Watts, J. (1996). Mapping plant biodiversity on Mt. Cameroon. In: L. J. G. van der Maesen, X. M. van der Burgt \& J. M. van Medenbach de Rooy (eds), The Biodiversity of African Plants (Proceedings XIV AETFAT Congress), pp. 110 - 120. Kluwer. https://doi.org/10.1007/978-94-009-0285-5_16

Etuge, M. \& Williams, S. (2019). Afrothismia kupensis sp. nov. (Thismiaceae), Critically Endangered, with observations on its pollination and notes on the endemics of Mt Kupe, Cameroon. Blumea 64 (1): 158 - 164. https://doi.org/10.3767/ blumea.2019.64.02.06

, Feika, A., Lebbie, A., Goyder, D., Tchiengue, B., Sene, O., Tchouto, P. \& van der Burgt, X. (2017). A synoptic revision of Inversodicraea (Podostemaceae). Blumea 62: 125 - 156. https://doi.org/10.3767/ blumea.2017.62.02.07

Gosline, G. \& Onana, J-M. (2018d). Vepris bali (Rutaceae), a new critically endangered (possibly extinct) cloud forest tree species from Bali Ngemba, Cameroon. Willdenowia 48: 285 - 292. https://doi.org/10.3372/wi.48.48207

, Harvey, Y. \& Onana, J-M. (2010). The Plants of Dom, Bamenda Highlands, Cameroon, A Conservation Checklist. Royal Botanic Gardens, Kew.

\& _ (2011). The Plants of Mefou Proposed

National Park, Yaoundé, Cameroon, A Conservation Checklist. Royal Botanic Gardens, Kew.

Mackinder, B., Gosline, G., Onana, J.-M. \& Achoundong, G. (2001). The phytogeography and flora of western Cameroon and the Cross RiverSanaga River interval. Syst. Geogr. Pl. 71: 1097 1100. https://doi.org/10.2307/3668742

, Nic Lughadha, E., Kirk, P., Lindon, H., Carretero, J., Looney, B., Douglas, B., Haelewaters, D., Gaya, E., Llewellyn, T., Ainsworth, M., Gafforov, Y., Hyde, K., Crous, P., Hughes, M., Walker, B. E., Forzza, R. C., Wong, K. M. \& Niskanen, T. (2020). New scientific discoveries: plants and fungi. Plants, People Planet 2: 371 - 388. https://doi.org/10.1002/ppp3.10148

Onana, J-M. \& Pollard, B. J. (2000). The Plants of Mount Oku and the Ijim Ridge, Cameroon, a Conservation Checklist. Royal Botanic Gardens, Kew.

Pollard, B. J., Darbyshire, I., Onana, J-M. \& Wild, C. (2004). The Plants of Kupe, Mwanenguba and the 
Bakossi Mountains, Cameroon: A Conservation Checklist. Royal Botanic Gardens, Kew.

, Prenner, G., Tchiengué, B. \& Faden, R. B. (2018b). Notes on the endemic plant species of the Ebo Forest, Cameroon, and the new, Critically Endangered, Palisota ebo (Commelinaceae). Pl. Ecol. Evol. 151 (3): 434 - 441. https://doi.org/10.5091/ plecevo.2018.1503

Tchiengué, B. \& van der Burgt, X. (2021). Taxonomic revision of the threatened African genus Pseudohydrosme Engl. (Araceae), with P. ebo, a new, critically endangered species from Ebo, Cameroon. PeerJ 9:e10689. https://doi.org/ 10.7717/peerj.10689

Tsukaya, H., Rudall, P. J. \& Suetsugu, K. (2018c). Taxonomic monograph of Oxygyne (Thismiaceae), rare achlorophyllous mycoheterotrophs with strongly disjunct distribution. PeerJ 6:e4828. https://doi.org/10.7717/peerj.4828

Dagallier, L.-P. M. J., Janssens, S. B., Dauby, G., BlachOvergaard, A., Mackinder, B. A., Droissart, V., Svenning, J.-C., Sosef, M. S. M., Stévart, T., Harris, D. J., Sonké, B., Wieringa, J. J., Hardy, O. J. \& Couvreur, T. L. P. (2020). Cradles and museums of generic plant diversity across tropical Africa. New Phytol. 225: 2196 - 2213. https://doi.org/10.1111/ nph.16293

Darbyshire, I., Anderson, S., Asatryan, A., Byfield, A., Cheek, M., Clubbe, C., Ghrabi, Z., Harris, T., Heatubun, C. D., Kalema, J., Magassouba, S., McCarthy, B., Milliken, W., Montmollin, B. de, Nic Lughadha, E., Onana, J. M., Sardou, D., Sarbu, A., Shrestha, K. \& Radford, E. A. (2017). Important Plant Areas: revised selection criteria for a global approach to plant conservation. Biodivers. Conservation 26: 1767 - 1800. https://doi.org/10.1007/ s10531-017-1336-6

Davis, A. P. \& Sonké, B. (2008). A new Argocoffeopsis (Rubiaceae) from Southern Cameroon: Argocoffeopsis spathulata. Blumea 53: 527 - 532. https://doi.org/ 10.3767/000651908x607486

Gosline, G. \& Cheek, M. (2014). Two new African species of Salacia (Salacioideae, Celastraceae). Blumea 59: 26 - 32. https://doi.org/10.3767/ $000651914 \times 682026$

GBIF (continuously updated). Global Biodiversity Information Facility: https://www.gbif.org/ (Accessed 23 Aug. 2020).

Harvey, Y., Pollard, B. J., Darbyshire, I., Onana, J-M. \& Cheek, M. (2004). The Plants of Bali Ngemba Forest Reserve, Cameroon. A Conservation Checklist. Royal Botanic Gardens, Kew.

, Tchiengué, B. \& Cheek, M. (2010). The plants of the Lebialem Highlands, a conservation checklist. Royal Botanic Gardens, Kew.
IPNI (continuously updated). The International Plant Names Index. Available from: http://ipni.org/ (Accessed March 2020).

IUCN (2012). IUCN red list categories: Version 3.1. IUCN Species Survival Commission Gland and Cambridge.

JSTOR Global Plants (continuously updated). https:/ / plants.jstor.org/ (Accessed March 2021).

Kenfack, D., Gosline, G., Gereau, R. E. \& Schatz, G. (2003). The genus Uvariopsis in Tropical Africa, with a recombination and one new species from Cameroon. Novon 13: 443 - 449. https://doi.org/ $10.2307 / 3393377$

King, C. \& Cheek, M. (2020). Nepenthes maximoides (Nepenthaceae) a new, critically endangered (possibly extinct) species in Sect. Alatae from Luzon, Philippines showing striking pitcher convergence with N. maxima (Sect. Regiae) of Indonesia. PeerJ 8:e9899. https://doi.org/10.7717/peerj.9899

Lachenaud, O., Droissart, V., Dessein, S., Stévart, T., Simo-Droissart, M., Lemaire, B., Taedoumg, H. \& Sonké, B. (2013). New records for the flora of Cameroon, including a new species of Psychotria (Rubiaceae) and range extensions for some rare species. Pl. Ecol. Evol. 146: 121 - 133. https:// doi.org/10.5091/plecevo.2013.632

Letouzey, R. (1957). La forêt à Lophira alata de la zone littorale camerounaise. Bois Forêts Trop. 53: 9 - 20.

(1960). La forêt à Lophira alata Banks du littoral camerounais. Hypothèses sur ses origines possibles. Bull. Inst. Etudes Centrafric. 19 - 20: 219 - 240.

(1968). Etude phytogéographique du Cameroun. Lechevalier, Paris.

(1985). Notice de la carte phytogéo graphique du Cameroun au 1:500000: 4) Domaine de la forêt dense humide toujours verte. Pp. 63 - 142. Institut de la Carte Internationale de la Végétation, Toulouse.

Mahmoud, I. M., Campbell, M., Sloan, S., Alamgir, M. \& Laurance, W. (2019). Land-cover change threatens tropical forests and biodiversity in the Littoral Region, Cameroon. Oryx 54: 882 - 891. https://doi.org/10.1017/S0030605318000881

Maas-van de Kamer, H., Maas, P. J. M., Wieringa, J. J. \& Specht, C. D. (2016). Monograph of African Costus. Blumea 61: 280 - 318. https://doi.org/10.3767/ 000651916X694445

Mackinder, B. A., Wieringa, J. J. \& van der Burgt, X. M. (2010). A revision of the genus Talbotiella Baker $\mathrm{f}$. (Caesalpinioideae: Leguminosae). Kew Bull. 65: 401 420. https://doi.org/10.1007/s12225-010-9217-0

Maisels, F. M., Cheek, M. \& Wild, C. (2000). Rare plants on Mt Oku summit, Cameroon. Oryx 34: 136 - 140. https://doi.org/10.1017/s00306053000 31057 
Onana, J.-M. (2011). The vascular plants of Cameroon, a taxonomic checklist with IUCN Assessments. Royal Botanic Gardens, Kew. \& Cheek, M. (2011). Red data book of the flowering plants of Cameroon, IUCN global assessments. Royal Botanic Gardens, Kew.

Prance, G. T. \& Jongkind, C. C. H. (2015). A revision of African Lecythidaceae. Kew Bull. 70, 6: 13. https://doi.org/10.1007/s12225-014-9547-4

Soltis, D. E., Clayton, J. W., Davis, C. C., Wurdack, K. J., Gitzendanner, M. A., Cheek, M., Savolainen, V., Amorim, A. M. \& Soltis, P. S. (2007). Monophyly and relationships of the enigmatic family Peridiscaceae. Taxon 56: 65 - 73.

Sonké, B., Dessein, D., Taedoumg, H., Groeninckx, I. \& Robbrecht, E. (2008). A new species of Colletoecema (Rubiaceae) from southern Cameroon with a discussion of relationships among basal Rubioideae. Blumea 53: 533 - 547. https:// doi.org/10.3767/000651908x607495

, Djuikouo, M.-N. \& Robbrecht, E. (2007) (publ. 2008). Calycosiphonia pentamera sp. nov. (afrotropical Rubiaceae) from the 'Lower Guinea' area. Nord. J. Bot. 25: 275 - 280. https://doi.org/10.1111/j.0107055x.2007.00141.x

Esono, P., Nguembou, K. C. \& Stévart, T. (2005). Une nouvelle espèce de Bertiera Aubl. (Rubiaceae) du sous-genre Bertierella découverte en Guinée Equatoriale et au Cameroun. Adansonia sér. 3, 27: $309-315$.
Nguembou, K. C. \& Davis, A. P. (2006). A new dwarf Coffea (Rubiaceae) from southern Cameroon. Bot. J. Linn. Soc. 151: 425 - 430. https://doi.org/ 10.1111/j.1095-8339.2006.00508.x

Sosef, M. S. M., Wieringa, J. J., Jongkind, C. C. H., Achoundong, G., Azizet Issembé, Y., Bedigian, D., Van Den Berg, R. G., Breteler, F. J., Cheek, M. \& Degreef, J. (2006). Checklist of Gabonese Vascular Plants. Scripta Bot. Belg. 35. National Botanic Garden of Belgium.

Stoffelen, P., Cheek, M., Bridson, D. \& Robbrecht, E. (1997). A new species of Coffea (Rubiaceae) and notes on Mt Kupe (Cameroon). Kew Bull. 52 (4): 989 - 994. https://doi.org/10.2307/4117826

Thiers, B. (continuously updated). Index Herbariorum: A global directory of public herbaria and associated staff. New York Botanical Garden's Virtual Herbarium. Available from: http://sweetgum.nybg.org/ih/ (Accessed March 2021).

van der Burgt, X. M., Mackinder, B. A., Wieringa, J. J. \& Estrella, M. de la (2015). The Gilbertiodendron ogoouense species complex (Leguminosae: Caesalpinioideae), Central Africa. Kew Bull. 70: 29. https://doi.org/10.1007/s12225-015-9579-4

\section{Publisher's Note}

Springer Nature remains neutral with regard to jurisdictional claims in published maps and institutional affiliations. 